Öztürk, Ahmet Erdi. "An alternative reading of religion and authoritarianism: the new logic between religion and state in the AKP's New Turkey." Southeast European and Black Sea Studies 19, no. 1 (2019): 79-98.

Submission date: 28 August 2018

Acceptance Date: 11 January 2019

Published Online: 26 February 2019

\title{
An Alternative Reading of Religion and Authoritarianism: The New Logic Between Religion and State in the AKP's New Turkey
}

\begin{abstract}
Since roughly 2011, the Turkish state and the ruling Justice and Development Party (AKP) have been going through a process of mutual transformation. Some of the historical apprehensions, biases and frustrations exhibited by Turkey as a middle power been absorbed by the relatively reformist AKP. Conversely, the AKP and its undisputed leader Erdogan have seen their socio-political fears, power based conflicts and ethno-religious desires become dominant in all areas, including religion. As a consequence of this bilateral transformation, Turkey has become both an inclusionary and a hegemonic-authoritarian state, and at the same time a weak one. Within this new identity and structure of the state, Sunni Islam has become one of the regime's key focal points, with a new logic. This article seeks to explain the transformation of the relations between the AKP's Turkish state, religion and religious groups, by scrutinising Karrie Koesel's logic of state-religion interaction in authoritarian regimes.
\end{abstract}

Key words; Religion, authoritarianism, Islam, Turkey, AKP 
Starting with the Westphalia Treaty, which stipulated the secularization of the land that belonged to Church in 1648 (Hurd 2004, 238), and until the last quarter of the 20th century, religion was expected to retreat from social and political life, rendering secularism the final station of human development (Berger 1969). Even though this proposition still exists with different interpretations (Farr 2008; Hanson 2006), currently, it is more commonly accepted that religion cannot be confined to the private sphere and that any effort in this direction violates the relationship between individuals and their religion (Juergensmeyer 1993; Casanova 2001a). In the early 1970s, the notion was put forward that religion could not be rejected as a political and social phenomenon, and even if rejected, it would continue to exist, albeit in different forms (Ben-Porat 2013, 4; Fox and Sandal 2013, 2). Starting with identities and behaviour patterns, (Kubalkova 2000; Katzenstein and Byrnes 2006) religion was believed to manifest itself both in domestic politics (Fox 2008; Norris and Inglehart 2011; Haynes 1994) and international relations (Snyder 2011; Froese and Mencken 2009; Sandal and James 2011). As a phenomenon that forever resurfaces, religion is currently discussed through the lens of the roles it plays in, among many others concerns, ethnic conflicts (Gurses and Rost 2017), the relationship it has with the economy (McClear and Barro 2006), and the issues of migration and integration (Hirschman 2004).

With the advent of the new millennium, the weakening of liberal democracy became clear: a process that can be called 'democratic backsliding'. Just like the landscape created jointly by the predictions regarding the future of secularism and the return of religion, the expectations around the strengthened establishment of liberal democracy are being thwarted by the rise of regimes that are distancing themselves from democracy. The 2017 Freedom House Report acknowledges that $25 \%$ of the countries it surveyed fell into the category of 'backward moves on democracy'i In this context, Norris (2017) emphasizes that the increasing security concerns in these countries have led to social fears, which in turn encourage populist-authoritarian regimes. Indeed, Norris's proposition chimes with the 'electoral authoritarianism' of Schedler (2013), the 'semi-democracy' of Case'in (1993), the 'illiberal democracy' of Zakaria (1997) and the 'competitive authoritarianism' of Levitsky and Way (2010): all definitions which frame those regimes that now distance their countries from democracy, against all previous expectations that they would evolve into established democracies. 
This situation of backward moves in contemporary liberal democracy has been studied with regards to economics, education, security, terrorism and similar factors, yet its relation with religion has been relatively less examined. There is broad acceptance of the thesis that secularism and liberalism are mutually supportive, but the antithesis has not been studied in detail, leaving untackled questions including the following: How is convergence between authoritarian-repressive regimes and religion and religious groups formed? What is the influence of this convergence on the rise of new regimes?

Unlike the relationship between religion and authoritarianism, the relationship between religion and democracy has been studied comprehensively (Elshtain 2009; Casanova 2001b). Fox and Flores (2009) state that there is no significant relationship between religion and democracy, and the findings of Coşgel and Miceli (2009) are that levels of democracy have no effect on state interference in religious affairs. One of the contexts in which the issue of religion and authoritarianism has been studied is that of the possibility of Islam's coexistence with democracy. Despite the fact that millions of Muslims live in relatively developed democracies, in peace (Cesari 2004), it has been argued that the hierarchy and patriarchy inherent in Islam clash with the essence of democracy (Sarkisian, Fox and Akbaba 2011).

Sudies on religion-authoritarianism, and more specifically on Islam-authoritarianism, do not however go any deeper than categorising the relationship between political and religious power centres. Karrie J. Koesel $(2013,2014)$ brings a different perspective to the modelling of relations between authoritarian regimes and religion. Defining regimes in Russia and China as 'repressive-authoritarian', Koesel focuses on the affiliations that different religious groups form with local and national political elites. In her study, she argues that religious groups form relations with local regimes on the basis of 'uncertainty', 'needs' and 'resources' and with the aim of mutual reinforcement. In other words, an intensely felt combination of uncertainty, mutual needs, and resources, she argues, tends to lead local politicians and religious elites to bargain and deal with one another in materially beneficial and strategic ways. This argument brings us to another question: Does this perspective explain all relationships between such groups and regimes? Does it work in countries other than Russia and China, the latter having historically weak relations with religion? Does it retain its explanatory power in the context of Islam? 
It would be possible to respond to these questions using the cases of Hungary and India, countries that have been ruled by repressive-authoritarian leaders since the early 2000s and where religion is a significant determinant on politics and society. This study, however, uses the case of Turkey, which provides various alternative avenues of explanation. Turkey was founded upon the Ottoman heritage, which can be defined as semi-theocratic, and has a population that is more than 99\% Muslim; yet, it has an understanding of secularism (in Turkish: laiklik) which is distinct from both Anglo-Saxon secularism and French laïcité. In the Turkish understanding of laiklik, religion is controlled, regulated and utilized by the state to play important socio-political roles. Furthermore, it is only the state that has the ability to categorise religious groups as official or unofficial, via various state apparatuses and laws. Since 2002, Turkey has been ruled by a religious-conservative elite, and in the initial years it was often cited as an example of how Islam can be at peace with democracy. But the political trajectory of Turkey, under the rule of Recep Tayyip Erdoğan, the man who has ruled Turkey and the AKP since 2002, has shown a rather interesting downward spiral: from conservative democracy to one-man-rule with a repressive government. This transition has been examined in social, economic, political and cultural terms (Baser and Öztürk 2017; Taş 2015); however, the relationship that this religion-sensitive government has with religious communities has not been studied in detail. This context is important for any study of the relationship between Islam and democracy, between authoritarianism and religion. The fundamental questions of this article are, then: how and under what conditions has a government that was formerly able to harmonize Islam and democracy in a secular setting turned into an authoritarian one that uses religion for its political ends? What is the underlying logic of this fundamental transition?

In the light of these questions, this article focuses on how the AKP and Erdoğan utilized religious groups in the aforementioned transition and on the relations that they formed with religious communities. In its inquiry, the article is informed by Koesel's 'logic of religious and state interaction in authoritarian regimes' and examines the validity of her proposition for the Turkish case. The article then summarizes state-religion-society relations and their historical trajectory in Turkey, and how they have been changed by the AKP governments. In conclusion, the Turkish case is evaluated in terms of the general propositions in the literature.

\section{The relationship between authoritarianism and religion: The logic of a multi-layered uncertainty}


The key proposition of secularism lies in the separation of the powerhouses of the mundane (politics/state) and the spiritual/otherworldly (religion/church) and in entrusting all worldly matters to the mundane one. However, in the terminology of Habermas (2008), we are living in a post-secular world, where the process of the 'de-privatisation of religion' (Casanova, 2001a) is blurring the boundaries between the mundane and the otherworldly, in the context of power, morality, legitimacy and spheres of influence. In this regard, both the mundane and the otherworldly have started to form common causes and to walk side by side, and this has resulted in conflicts, negotiations and reconciliations. Religious communities that established themselves through non-governmental organisations succeeded in influencing and even keeping some governments under pressure (Encarnacion 2003). Some of these religious communities, however, have opted to remain silent on political debates and to support repressive-authoritarian regimes, albeit cautiously (Gill 2002). All these different attitudes manifested by religious communities have inflamed the debates on the relations between religion, democracy and authoritarianism.

Most studies on such relations focus on the positioning and orientation of religious communities vis a vis democratic or authoritarian political actors and systems. Working with a comprehensive set of data, Fox $(2008,136)$ concludes that in countries with established liberal democracies there are higher levels of religious tolerance, and religious minorities support democratic development. In other countries, however, the dominant religious perspective is formed in conjunction with nationalism, and this empowers right wing politics, thus increasing exclusivism (Smith 1999). Some studies indicate that in countries where Catholicism is dominant the church and religious groups can, in rare exceptions found usually in Latin America, promote democracy by means of their strategic concerns (Kalyvas 2000; Warner 2000). Some other religious groups, such as the Quakers (Angell and Dandelion 2015), have been observed to support democracy and peaceful order throughout their history. In brief there is no agreed upon perspective on the interactions between religion, democracy and authoritarianism. The debate focuses, and oftentimes gridlocks, on the compatibility of Islam and democracy. Inglehart and Norris (2004) studied the relationship between religion and many other political phenomena in different countries and concluded that despite the absence of difference between different religions in terms of their perspectives on democracy, in countries where Islam is more dominant, a relatively less developed democracy is observed. This relative difference, it has been claimed, can be explained by the discrepancy between the theory and the practice of Islam (Stepan 2000, 48-49). However, there is a limited number of examples of 
compatibility between Islam and the democratic authority of the state (Haynes 2006, 490). The initial years of the AKP have been cited as an example of such compatibility (Gunter and Yavuz 2007; Hale and Ozbudun 2009), but the authoritarian turn taken subsequently by the AKP supports the thesis that Islam promotes authoritarianism.

Kuru (2014) refutes the claims that Islam innately promotes authoritarianism, and that therefore democratic secularism cannot thrive in countries where Islam is the dominant religion. He also objects to the arguments that Islamic patriarchy is a result of Islam's innate authoritarianism, and points to other factors to explain the existing situation: '... geology and geography that primarily lead to the disproportionate authoritarianism in Muslim-majority countries' (Kuru 2014, 426). Kuru refers to the concept of 'rentier state' as a determinant in this context, acknowledging countries in the MENA region as rentier states and pointing to Soviet tradition in explaining the presence of a similar situation in Central Asian countries. He tries to provide an alternative explanation to the popular argument that Islam creates authoritarianism by its very nature, by involving other factors that pertain to infrastructure. However, he offers no crystal clear explanation in his examination of the relations between religious groups and political authority, as to how such relations are formed or who plays the dominant roles in regulating them.

The existing literature is less than satisfactory in explaining the internal workings of authoritarianism at a time when religion and politics affect each other in different ways. Indeed, this is not a vital research question for most scholars in the field. Yet, in the Turkish context, a similar question that rises in this article is: How have religious groups that have been historically oppressed by the secular state come to seize power, only to establish an even more authoritarian structure? Framed as such, this question takes the debate away from the popular discussions on the political nature of Islam and democracy and builds it, rather, on the major considerations of politics, such as power, interest and authority. If one wants to bring together religious and political actors to analyse in this context, one can use Driessen's (2014) concept of 'religion friendly democratization', a term he coined after his studies on post-World War II Italy and post-colonial Algeria. Driessen argues that in certain spatio-temporal settings, religious communities and democratization can work together; but the sustainability of this coexistence depends on mutual will and capacity for cooperation, entailing a constant process of 'bargaining'. 
The bargaining process requires relatively equal capacities in the bargaining parties, which is possible to a certain extent in modern authoritarian-repressive regimes that hold elections. In her seminal work, Religion and Authoritarianism: Cooperation, Conflict and the Consequences (2014), Koesel examines the relations between religion, religious groups and political elites in two authoritarian-repressive regimes: China and Russia. Using the rational actor approach, Koesel indicates the presence of a high level of cooperation, alliance and mutually beneficial relationships between religious groups and political elites. She claims that both the religious groups and local politicians survive by relying on each other within the authoritarian regime. In this regard, the elements of mutual legitimacy, material benefits and the need for resources are a sine qua non at the bargaining table. The religious groups do not need to confront the authoritarian regimes, since they get what they want from the regime and see its authoritarianism through the lens of stability. According to her, religious community elites and their authoritarian political leaders are cooperating around the core issues of politics, financial resources, socio-political power and impact on social groups.

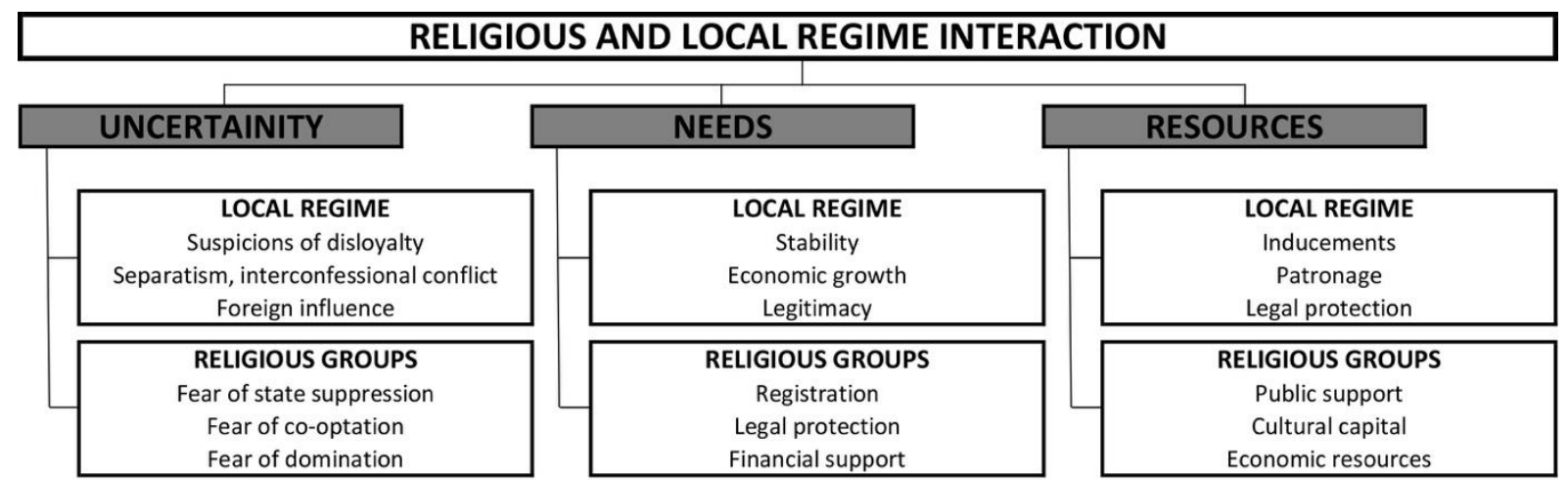

Figure 1: Koesel's figure on religious groups and local authoritarian regime interactions, Koesel $(2014,16)$.

Some issues pertaining to Koesel's logic may vary in different contexts, yet, the issue of uncertainty remains almost constant, because of the weak institutions and overall nature of authoritarian regimes (Koesel 2014, 16). She evaluates this common uncertainty as being a result of mutual lack of trust. The lack of trust stems from two things: first, the authoritarian regimes have no significant confidence in themselves, and second, the religious groups do not feel safe, regardless of their position in the eyes of the regime. The most important element of the logic is the absence of trust. Though this perspective emerged from a study conducted in 
Russia and China, it may be used in different geographies where religion, power and authority intertwine. With its recent transformations, Turkey falls within this category.

After the 1990s, both Russia and China reconstructed their dominant religion, but tried to keep it under control, despite great resistance from society. This is a practice that has been implemented by many ancient empires. A dominant religion that can be reconstructed can also be utilized for the purposes of religiously oriented nation building processes. According to Koesel (2014), a game of bargaining, conflict and cooperation takes place between the decisionmakers of the regime and religious communities. The choice of those groups with whom the game is to be played is determined by their influence capacity and their political and financial powers. The rules, players and positions of the game may change, but there is always a logic that fits the needs of the game. So, how did this reconstruction of the relationship between the dominant religion and laiklik, with its fear-based bargaining, take place in Turkey, a country that has recently transformed from a problematic democracy to yet another regime that involves religion in its discourse and policymaking?

\section{State-religion relations in Turkey: A long fight against the laik state}

This cause is a cause for all of us. If we support it, we will win together. If we don't, we will lose together $\mathrm{r}^{\mathrm{ii}}$

These are the words of Turkey's president, Recep Tayyip Erdoğan, at a press conference that he held with the leaders of religious communities in the city of Diyarbakır, before the 2018 presidential and parliamentary elections, which officially started the presidential system in Turkey. It would be considered normal in other countries for a political leader to ask diverse organizations for votes, yet, in the historical trajectory of Turkey, it was unprecedented. The Turkish state does not recognize religious orders and communities and controls religion through an official religious discourse by means of a transnational state apparatus called Presidency of Religious Affairs (Diyanet Işleri Başkanlı̆̆l, Diyanet) (Gözaydın 2009; Mutluer 2014; Lord 2018). The formation of a socio-political union between a political party and the leaders of religious communities goes against the Turkish understanding of laiklik, which has taken shape over the last century. 
The formative years of the Turkish Republic were heavily influenced by reform movements in the late Ottoman era, more specifically the Tanzimat (Reorganisation) Era between 1839 and 1876. As argued by Mardin (1971), the young republic combined some of the state-religion relations of the Ottomans, though with a state centric approach, and therefore formed a hybrid structure. Just like the reformists, those repressive cadres of the Empire, namely revolutionary activists or the Committee of Union and Progress (Ittihatçllar), the ruling elite of the new Turkish Republic was concerned about the influence of religious orders and therefore wanted to keep them under state control. To this end, the Republican administration abolished the Caliphate in 1924, alongside the practice of Sharia Law and the activities of religious orders and lodges. A state institution, Diyanet, was formed to control religious discourse and practice in line with the overall policies of the state (Öztürk 2016, 621-625). This, however, created a dual structure involving both official Islam, which is promoted by the state and unofficial Islam that is not fully endorsed by the state, or allowed representation in public spaces (Akgönül 2005; Cizre-Sakallığlu 1996, 234). Unofficial Islam has survived this top-down discrimination and continued to exercise influence on the masses, despite the state monopoly on Islamic discourse and practice.

Likewise, the Ittihatçı cadres, the laik republican elites, with their Westernised, protectionist and top-down constructivist agenda, expected unofficial Islam to disappear in time. With the beginning of the multiparty system in 1950, however, they realized how vibrant religion was, and that it might be instrumentalized for political aims. The state authorities, to discredit unofficial groups such as the Nurcu Movements organized and led by Said Nursi, designated them as 'significant other' (Mardin 1989). In contrast, observing the vibrancy of Islamic demands, the Republican People's Party (Cumhuriyet Halk Partisi, CHP), the very political organization most likely to prohibit religious visibility in the public space, expanded the legitimacy of state oriented religion. The CHP government opened Islamic schools called Imam-Hatip Schools and a new theology faculty in Ankara University and increased the budget of Diyanet, to win the hearts of, particularly, the peripheral, lower class and rural masses who were mainly against to the repressive laik policy implementations of the early Republican CHP (Harris 1979, 21).This charm attack by the CHP did not, however, prevent its failure against the Democrat Party (Demokrat Parti, DP), whose founders had once been CHP members.

The decision making elite of the DP was comprised of conservative peripheral dignitaries and urban CHP opposition and the party was broadly supported by those who were not content with 
the laik policies of the CHP. Without actually positioning itself against the laiklik of the CHP, the DP introduced a softening in the repressiveness of the state in its initial years. The azan, the Muslim call for prayer, for example, was reconverted to its original Arabic form after 17 years of recitation in Turkish, which had been enforced by the CHP. The DP eased the conditions of leaders of religious opinion, starting with the influential Said Nursi, and lifted the prohibition on religious protests in public spaces. This created opportunity structures for unofficial Islam and a loose alliance between centre-right parties and Islamic groups started to form. The DP's relatively democratic stance lost momentum in the second half of the 1950s and the party started to implement oppressive policies (Simpson 1965). Yet it did not shed the loose connection with Islamic groups. The sustainability of this alliance can be explained with the help of the logic offered by Koesel, according to which the parties to the alliance need each other, therefore maintain the alliance despite oppressive policies. The inability of the laik opposition to offer breathing space to religious groups provided huge opportunity to the centre-right conservative parties: opportunities that the latter were able to exploit, with no significant rival.

The DP experience came to an end with the first military intervention in 1960. The coup administration increased the authority and scope of Diyanet, in order to diminish the influence of unofficial Islam on society. In 1965, the expression, ‘...to enlighten Turkish society about religion' (Gözaydın 2008, 220) was added to the tasks assigned to Diyanet. The efforts of the coup administration to curb the effects of unofficial Islam on Turkish society did not bear fruit for long. The era of right wing governments in Turkey further complicated state-religionsociety relations. While the centre-right Justice Party (Adalet Partisi, AP) of Süleyman Demirel started opening Imam-Hatip Schools providing Islamic education, unofficial Islamic groups, such as the Nurcu Movements, started to establish their position in politics and in the bureaucracy (Cizre-Sakallıoğlu 1996, 239-240).

Perhaps one of the most important socio-political developments in Republican Turkish history is the formation of this loose alliance between right wing governments and Islamic groups in the late 1960s and at the very beginning of the 1970s. Further right on the political spectrum lay the National Outlook Movement (Milli Görüş Hareketi, MGH) of Necmettin Erbakan, which represented 'the first and real' political Islam in Turkey. Being a smaller coalition partner in the mid 1970s and a bigger one in the mid 1990s, the parties of the MGH earned the votes of some religious groups, with their discourse against the established secularism of Turkey. This representation of unofficial Islam at state level marked a less-than-desirable convergence for 
the secularly oriented state elite. The Islamic groups were only given such position because of the concern about a rise of socialist movements in society: the Islamic groups were the only remedy that the authorities could offer. The Naqshbendi Sufi tradition, for example, started to gain influence in society along with its economic activities, and started to support MGH in explicit ways (Cizre-Sakallığlu 1996, 241). It was in the late 1970s too that religious Kurdish groups started to become more visible. Simultaneously, the Gülen Movement, which would later exert huge influence on state and society, also started to organize under the leadership of Fethullah Gülen (Yavuz 1999).

This convergence of unofficial Islamic structures with the state structure and bureaucracy, and its acceptance within certain frameworks, took place after the 1980 military coup and the following centre-right governments of Turgut Özal. In this context, official Islam represented by Diyanet started to increase its power and influence both in Turkey and in European countries with a significant Turkish diaspora (Öztürk and Sözeri 2018, 629; Çıtak 2010, 611). Unofficial Islamic groups started also to be more visible at state level (Bruce 2015, 87-95). Despite the fact that the 1980 military coup was instigated with a laik-Kemalist mind-set, it paved the way for Islamic groups to gain influence in state and society. The unspoken paradigm of the coupmakers, Turkish-Islamic Synthesis (Türk İslam Sentezi, TIS) gained strength and Islamic groups such as, Naqshbendi, Süleymanci and Nurcu groups started supporting the Motherland Party (Anavatan Partisi, ANAP) of Özal (Yavuz 1997, 69). The convergence between Islamic groups and the state would be the socio-political basis of the transnationalization of Diyanet in later decades.

Despite the displeasure of the laik-Kemalist state elite, with their tutelary perspective on democracy and the rise of unofficial Islam, and the established belief that the Republic should monopolize Islamic discourse through Diyanet with restraint of the unofficial Islamic groups, the entry of these groups into politics at the time of Özal bore fruit in the 1990s. Beyond that, the Welfare Party (Refah Partisi, RP) won both local and general elections in the mid-1990s, under the leadership of Necmettin Erbakan (Yeşilada 2002). Seemingly, this was victory for political Islam, which had been pushing through towards the socio-political core since the 1930s. However, Erbakan's electoral base did not include all Islamic groups. One such group was the Gülen Movement, which had never appreciated political Islam, directly, in its domestic and foreign policies, and therefore had rather tense relations with the Erbakan tradition. Furthermore, the laik elite was extremely agitated by the political popularity of Erbakan and 
his disciples, one of which, Erdoğan, would later rule the country for two decades. The laik elite, its media arms and indeed the military, then, carried out the postmodern coup of February 28, 1997 (Aslan 2016), to cripple political Islam as well as other non-politicized Islamic groups, in both social and political terms. The coup ousted Erbakan from his post as prime minister and silenced Fethullah Gülen and most other leaders of Islamic groups. In spite of this attempt to diminish them, the Islamic groups, political or not, survived the oppressive secularist policies, adapting to the new conditions.

Throughout these years, though Turkey's political regime was certainly less-than-democratic in terms of the general characteristics of contemporary liberal democracy, it cannot nevertheless be regarded as fully authoritarian. However, the relationship between state mentality and religious groups was consistent with Koesel's proposition of the logic of religion and state interaction in authoritarian regimes, which is built upon the 'resources', 'needs' and 'uncertainty' on the side of the religious groups. As explained in figure 2, the presence of mutual interests necessitates collaboration between the two parties. Unofficial Islam, which had been pushed outside the socio-political core and denied full representation in the public space, now marched towards that core on the back of the centre-right parties, with a cumulative effect on state bureaucracy. Official Islam also grew and went through a kind of rapprochement with the unofficial groups. As needs and resources were bringing the unofficial Islamic groups and political actors together, the established state mentality disrupted the 'cooperation logic', utilizing 'uncertainty' for the purposes of protecting laiklik. However, the AKP sets an alternative example which is quite difficult to define within the borders of the Turkish understanding of laiklik, but with a new logic between state and religion.

\section{The 'Muslims' march to the centre of the state: Formation of the AKP and its hold on power}

Coming from the Erbakan National Outlook tradition, but rejecting its anti-Western rhetoric in favour of integration with the Western world and a market-based neo-liberal economy, and with a relatively cosmopolitan discourse, the religiously sensitive AKP came to power in 2002 (Öztürk 2014, 110-118). The AKP's accession to power was alarming for Kemalist-laik groups, yet it inspired a huge portion of society from the centre-right, as well as a small number of liberals who enjoyed significant intellectual impact on society. One might say that the AKP's seizure and maintenance of power until late 2007 can be evaluated as a result of the logic that 
was formed between the repressive state structure and unofficial Islamic groups. Unofficial Islamic groups that were denied full representation by early Republican policies started their march towards the centre in the early 1950s, and with the economic vibrancy brought about by Özal's incentives following the 1980 military coup, they started to form an Islamic bourgeoisie: first in Anatolia and then in İstanbul. A combination of religiously sensitive politicians, the newly emerging bourgeoisie and an intelligentsia that was pro-European Union and antiKemalist, ripened the conditions for a new conservative elite, which would be the electoral base for the AKP. In its initial years, the AKP brought pluralist democratic elements to the fore, rather than outright Islamism, and tried to establish a new government mentality: not an easy struggle against the laik-Kemalist block within the state structure.

The inherent tension between the established state mentality that wanted to keep Islam in check in repressive ways, and a government that defined itself as religiously sensitive, erupted into conflict multiple times between 2002 and 2007. For the economy, the AKP followed the policies largely laid down by the preceding government and the International Monetary Fund. In foreign policy the party constructed pro-European Union policies, with extensions in domestic reforms (İnsel 2003). The laik-Kemalist establishment, which manifests itself through the CHP in politics, through the Supreme Court of Appeal and the Constitutional Court in the judiciary, and more importantly with the Turkish Armed Forces, started to fight not only the AKP but also the unofficial Islamic groups, with the assumption that they shared the same agenda.

At this juncture, Turkey started to drift away from both Koesel's 'logic', and the logic that had been created during the 28 February process, increasing uncertainty in the country, to the point of conflict. the ties between the unofficial Islamic communites and the state started to disappear and these groups started then to transfer their allegiances to the AKP governments. The AKP might be in government; but the mighty bureaucracy of Turkey had no intention of loosening its grip on power. The AKP's hold on the executive branch toughened the laik-Kemalist establishment's measures against the Party and therefore the tension between the state and the AKP government, with its supportive groups, was transferred to the different organs of the state.

Amidst global concern regarding radical Islamism in the aftermath of the 9/11 attacks, the AKP's initial moderate and market and liberal democracy friendly position was welcomed by the majority of influential liberal groups both in Turkey and abroad. Yet still, the laik-Kemalist 
establishment was convinced that it needed to stop the conservative march to the core of the state, and the ensuing control of the economy and bureaucracy, and it came up with the slogan; 'Turkey is laik, it will remain so!' (Türkiye laiktir laik kalacak). They organized mass demonstrations to mobilize supporters, under the leadership of the Atatürkist Thought Association (Atatürkçü Düşünce Derneği), though it is debateable as to whether this organization is really a civic initiative, or rather a tool of psychological warfare used by retired army members. On April $27^{\text {th }}$ 2007, the chief of staff posted a memorandum on its website warning the AKP government about its 'anti-laik' activities. Finally, the establishment resorted to what it has always used against pro-Kurdish and Islamist parties: closure of 'dangerous and objectionable' political parties. The Supreme Court of Appeal opened a court case demanding the closure of the AKP, with the accusation that the party had become the focal point for antisecular activities. The court also asked for a prohibition from politics on Erdoğan and the leading cadres of the party.

None of these measures by the laik-Kemalist establishment bore fruit and the AKP came out of these crises stronger. Harvesting the support of conservatives, unofficial Islamic groups, nationalists and liberals, Erdoğan and his party overcame the systemic traps laid out by the laikKemalist establishment. One specific movement within the supporters' base of the party came to the fore: the Gülen Movement. Even though the Movement was famous for its para-political activities within the state structure (Watmough and Öztürk 2018a), it declared itself as a propeace and education oriented movement. However, the laik-Kemalist establishment was concerned about its Islamic inspiration and almost obvious political motivations, which included seizing control of the state through the bureaucracy.

Targeted by the powerful laik-Kemalist elite, the AKP sought alliance with the Gülen Movement, which constituted a huge part of Turkey's educated labour force. The convergence and the ensuing alliance between the two was a result of ideological, political and economic transformations of Islamic movements in Turkey (Atay 2017, 42). The maintenance of this alliance was instrumental in the joint struggle against the laik-Kemalist establishment, which had historically been an enemy for most Islamic unofficial structures and movements. The AKP-Gülen Movement convergence was formed in contrast to the historic 'logic' between the laik-Kemalist state and religious-conservative society. The alliance fought against the laikKemalist tutelage and created a new model and/or logic of relationship between the state and religious groups. This new logic was interest and power oriented, and a result of the common 
objective of removing the laik-Kemalist tutelage within the state structure. The newly formed alliance involved other religious communities, but the Gülen Movement's domination and powerful influence on society and state bureaucracy rendered these other groups less-thanvisible.

The AKP-Gülen Movement relationship and/or unofficial coalition, which defined most of the traumas of the second decade of the 2000s, had a different logic of its own. The Gülen Movement, as it defines itself, was founded in the 1970s on the basis of Said Nursi's core ideas and under the new paradigm proposed by Fethullah Gülen. Even though it suffered from the 28 February process, like the other unofficial Islamic groups, since the beginning of the 1980s, with the impact of the increasing influence of unofficial Islam in Turkey, the Gülen Movement became visible in the civilian bureaucracy, the media, the business world and civil society. More profoundly, it set its stamp on the private education sector, to establish a new generation which would be compatible with Gülen's ideas. In the first decade of the 2000s, the AKP's initial pro-Western discourse had a huge appeal for moderate and well-educated Gülen Movement members and sympathizers. Until the beginning of 2013, the alliance between the two was strong in multidimensional ways: while the AKP provided public support for their fight against laik-Kemalist tutelage, the Movement employed its influence on the judiciary and bureaucracy. The fight against laik-Kemalist tutelage was promoted by the Gülenist media and was celebrated by the liberal intelligentsia of the country. Yet, this fight also created a huge space of uncertainty, as it started to unravel the established behaviour patterns of the state.

To be more precise, the fight against laik-Kemalist tutelage and uncertainty among these two different groups were manifested in the Ergenekon and Sledgehammmer (Balyoz) trials after 2007. Many high ranking officers, academics and journalists were accused of having acted in an organized manner since the beginning of the AKP period, plotting coups against the democratically elected governments. Despite problems with the proceedings and the legality of the evidence that was brought to the court, many people were imprisoned. The proceedings were fully supported by the Gülenist media and this created a perception that it was the Gülenist cadres in the judiciary who were running the cases, with the AKP providing popular justification (Öztürk 2018). Furthermore, with their international civil society organisations, the Gülenists sent the message to international society that the cases were legitimate and that Turkey needed to get rid of laik-Kemalist tutelage, in order to achieve its contemporary liberal democracy. The alliance also worked together for the 2010 Constitutional Change Referendum 
in a coordinated manner and the Gülenists broadly voted for the AKP for a significant period of time (Taş 2018, 398).

This alliance of the AKP and the Gülen Movement against Kemalist-laik cadres within the state structure relied on three principles. First was the common purpose of removing the laikKemalist cadres from high levels of bureaucracy, primarily the judiciary and the Turkish armed forces. These positions then would be filled with Gülenists and AKP supporters, making the alliance competent beyond being government. The second pertained to creating a negative perception about the laik-Kemalist elite and showing them as coup-organizers with no regard for public opinion. The third involved opening more space for Gülenists and AKP supporters in the fields of politics, the economy, the media, academia and even art. Under these principles, the alliance also provided more space for unofficial Islamic groups other than the Gülenists and created opportunities for them in important positions. For instance, the Ministry of Health was primarily occupied by the Menzil community. However, until 2012, the alliance between the AKP and the Gülenists continued as if it was an alliance focused on harmony between liberal values and democracy, and therefore, unofficially, this partnership excluded the other unofficial Islamic movements that remained outside this framework. In this regard, there was an unspoken hierarchy between the Gülen Movement and other unofficial Islamic movements. With its alliance with the Movement, the AKP was able to remove the laik-Kemalist elite from critical decision making positions and further establish its hold on power.

In the first decade of the 2000s, the Gülen Movement and other unofficial Islamic groups were not the only religious structures empowered by the AKP governments. Official Islam also gained a degree of power within the state structure and therefore its influence increased. In this regard, Diyanet, as the representative of official Islam, claimed its share of the economic growth that took place between 2002 and 2008 and increased its budget, personnel and the number of mosques in the country (Ozzano and Maritato 2018). This growth reflected on the activities that Diyanet organized through its subsidiaries, or foreign branches, in order to support the religious initiatives of other countries in the Balkans (Öztürk and Gözaydın 2018) and continental Europe. Furthermore, Diyanet started to make policies that were completely in line with AKP policies, providing them with religious justification. Diyanet has always been an important transnational state apparatus, but under a stable government that was religiously sensitive and with the support of unofficial Islamic groups, it reached unpredicted levels of influence. 
The alliance between the AKP, the Gülen Movement and some other unofficial Islamic groups, along with the enlargement of Diyanet, brought about three situations. First of all, the laikKemalist elites, for the first time in Republican history, were pushed into a defensive position. particularly with the beginning of the Ergenekon and Sledgehammmer trials. Secondly, the bureaucratic positions that had been previously occupied by laik-Kemalists started to be filled by the AKP's supporters, members of the Gülen Movement and of some of the other unofficial Islamic groups; and this paved the way for a change in state identity. Lastly, the historic relationship between the state and religious groups ceased to exist, as of 2010. An enormous uncertainty loomed because there was no clarity as to who was ruling the state and how influential all these groups were. The new logic, then, was based on uncertainty and transition, and this further consolidated the AKP's grip on power.

Struggle for the power centre: The new logic constructed by unofficial Islamic groups and the AKP

The alliance between the AKP and the Gülen Movement, which aimed at changing the core of the state identity, was a coalition without clear-cut rules and with a great many uncertain areas, such as the position of the alliance within the state structure, bureaucracy, and jurisdiction. Beyond that, as of 2012, the AKP had no meaningful competitor in the political realm, the laikKemalist bureaucratic resistance being crushed to a serious extent by the alliance. Then, the alliance started to crack from within and very soon there emerged one of the most violent conflicts of the Rebublic's history. This conflict and its aftermath created a new logic between state, religion and religious groups.

One might argue that the primary reasons for the conflict were the management styles of the leaders of the two parties and their power oriented competition. Both Erdoğan and Gülen have the final word in their leadership and neither of them likes criticism. They are both strong leaders who would not accept living under mandate. Another reason lies in the nature of the alliance: once they were convinced that they had successfully removed a significant part of the laik-Kemalist cadres, conflicts of interest emerged and they seem to have begun to dispute who would control what. A closer scrutiny, however, would indicate more fundamental differences: the Gülen Movement and the AKP had no consensus on the future of Turkey. While the Gülen Movement promoted pro-Western policies, as cover for their para-political agenda (Watmough and Öztürk 2018b), the AKP and Erdoğan distanced themselves from the West and started to 
instigate repressive policies. Furthermore, the two sides were not able to agree upon policies to solve some of Turkey's fundamental problems: for instance, the Kurdish issue. Eventually, these underlying conflicts of interest rose to the surface and the fight between the two sides became public.

The conflict can be evaluated as a fight between two structures each exploiting religion in its own way. The initial dispute, at least publicly, was the Mavi Marmara flotilla crisis ${ }^{\mathrm{iii}}$. While Erdoğan was keen to put pressure on Israel, Gülen was against conflict with the Israeli authorities because of Israel's close ties with Western powers. This dispute was reflective of how the two parties read the world. Then the head of the national intelligence organisation of Turkey, Hakan Fidan, was called for questioning by prosecutors close to the Gülen Movement, because of the negotiation talks with the Kurdistan Workers' Party (Partiya Karkerên Kurdistanê-PKK), which intelligence officers had held in Oslo in 2009. Erdoğan intervened and Fidan did not go for questioning. It was becoming clear that the two sides were having fundamental disputes and there was no search for consensus.

Additional to the crack in the informal coalition between the Gülen Movement and the AKP, in 2013, the Gezi Protests increased the level of oppression by the AKP's Erdoğan, with further securitization in domestic policies. In the following period, Erdoğan decided to shut down college preparatory courses, a crucial revenue and the public face for the Gülen Movment. This was the first public manifestation of the conflict between the Gülen Movement and the AKP governments. Furthermore, it was indicative of the high level of uncertainty between a strong and somewhat authoritarian government and the most influential Islamic movement. The uncertainty further increased with Gülenist prosecutors' 'corruption cases' at the end of 2013 against cabinet members of the AKP government, which may have involved Erdoğan himself. Addressing its power within the bureaucracy, Erdoğan lashed out at the Gülen Movement and called it 'the parallel state'. The corruption cases were inconclusive and in return, Erdoğan started his purge of Gülen Movement members in the bureaucracy and other state structures.

In the aftermath of the corruption prosecution, the AKP started to shut down the institutions of the Gülen Movement, including schools, finance institutions, publishing houses, radio and TV channels and civil society organisations such as international associations and foundations. In return, the Gülen Movement used its international network to intensify its criticism against the AKP, portraying it as corrupt and authoritarian. Influential members of the Gülen Movement 
were direct in their criticism, particularly on international platforms, yet they have never publicly acknowledged their own political agenda. This conflict situation has created an opportunity for other unofficial Islamic groups. As mentioned by Atay $(2017,49)$, the positions that became vacant after the Gülen Movement purge started to be filled by conservative unofficial Islamist groups such as; Naqshbendi, İsmailağa and Menzil, forming a new logic between the state, now run exclusively by the AKP and the unofficial Islamic groups.

The most fundamental change in the logic took place with the July 15, 2016 coup attempt. In the first hours of the attempt, Erdoğan declared the Gülen Movement as the mastermind of the coup and started to call it the Fethullahist Terrorist Organization (Fettullahcı Terör Örgütü, FETÖ). Even though the majority of the armed forces had not joined the junta and the coup was successfully aborted, the attempt paved the way for recrimination against the Gülen Movement by Erdoğan and the AKP, and this recrimination was embraced by an overwhelming majority in society. Right after the coup attempt, all the institutions of the Gülen Movement were shut down and Erdoğan declared a state of emergency for almost two years. Tens of thousands of members and/or sympathizers of the Gülen Movement were imprisoned and thousands fled the country. Erdoğan defined the coup attempt as 'a gift from God'iv and used it to justify the repressive regime that he had already constructed. In April 2017, there was a referendum for constitutional amendment and Erdoğan replaced the parliamentary system with a presidential one. Then in June 2018 he was elected as the first president of the new regime and made the state of emergency permanent, embedding it into the new regime.

This conflict and the authoritarian turn, the result of the struggle between the Gülen Movement and the AKP, has created the new logic between state and religion in Turkey. In other words, the AKP utilized every instrument and opportunity that the state provided in its 'war' with the the Gülen Movement and in some places it has been successful in discrediting the Movement. Institutions like Diyanet, for example, were used to gather intelligence on the Gülen Movement outside the country. The repressive measures that Erdoğan -and the state- have taken against citizens of the country, when they form organized opposition within the state and society, have been a clear message for other Islamic communities. Considering that the Gülen Movement was stronger than all other Islamic groups combined, no other group stands a viable chance to execute any plan against this government. As for the political authorities, they have learned how dangerous it can be when a specific group (particularly an unofficial Islamic movement, 
like the Gülen Movement) is favoured to the extent that it follows its own agenda. This situation has created the new logic between state and religion.

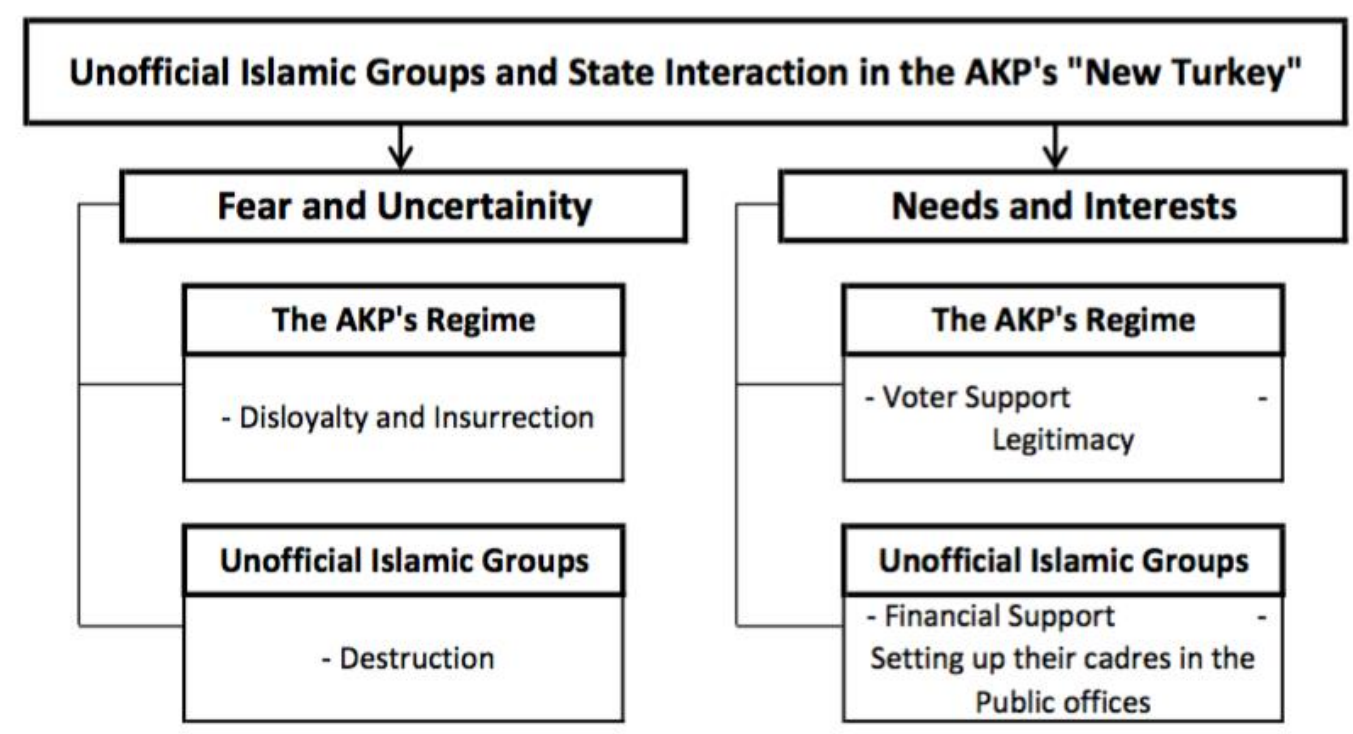

Figure 2: AKP's New-Turkey's logic between unofficial religious groups and state.

In this way, Erdoğan has transcended the position of a political leader and is currently endorsed by almost all the Islamic groups as a 'somewhat supreme' leader. In this regard, one might argue that, despite their historical orientation on the right of the political spectrum, Islamic groups in Turkey have never before been politicized to such an extent. In the processes of the 2017 referendum and the 2018 presidential elections, some of the very influential unofficial Islamic groups like İsmailağa and Menzil and many other Islamic communities openly supported Erdoğan through their foundations, associations and media. ${ }^{\mathrm{v}}$ It would be logical to read this support as a reaction by these groups to the extremely fresh and vivid story of the Gülen Movement and the new level of uncertainty, 'as a matter of survival'. There are also, of course, more 'normal' expectations for the support of unofficial Islamic groups for Erdoğan, such as obtaining employment within the state or winning state tenders, an important 'incentive' in the Turkish economic system. While uncertainty remains at an alarmingly high level for the unofficial Islamic groups, there is a clear determination on the part of the Erdogan-led state to wipe out all the oppositional Islamic structures A critical voice, the leader of the Furkan Foundation, has been imprisoned, perhaps to set an example ${ }^{\mathrm{vi}}$. And while the visibility of the unofficial Islamic groups has increased, their actual influence has decreased vis a vis the strong, 
authoritarian state represented by Erdoğan. In this regard, 'Erdoğanism' has been a sort of 'Wolf dressed in sheep's clothing' for these groups, and it is questionable as to how long they can maintain their present civic nature under the influence of such huge uncertainty in the new logic.

\section{Conclusion}

This article, essentially, aimed to explain how relations between religion, state and religious groups evolve and exercise influence on authoritarianism in the Turkish case. What primarily distinguishes the Turkish case from the cases mentioned in Koesel's study is the establishment of hegemony over state apparatuses by the Erdoğan-led AKP in the aftermath of the traumatic struggle with the Gülen Movement, and the following transformation of the state. This transformation has become possible firstly through the instrumentalization of Islam as a tool and an aim by the AKP, whose leading cadres and supporters are largely religious, and secondly through the repression of unofficial Islamic groups over the case of the Gülen Movement. The combination of the two created a new logic bringing together the legacies of the two historical traditions: the Islamism of Abdulhamid II, and a Unionist (Committee of Union and Progress) management style. Indeed, this idea is not unique for the relation between religion-religious groups and the state: it is rather the new characteristics of the AKP's Turkey. In a recent interview, senior Turkish journalist Cengiz Çandar defined Erdoğan-led Turkey as follows:

What they call the 'New Turkey' is a combination of Young Turks' state centric and revolutionary activism (Committee of Union and Progress-Ittihatçıllk), which has put an end to the Ottoman Empire, and Islamism, with reference to Abdulhamid II. It seems that the deep state that is Ittihatçılık in essence, which has committed genocide, mass killings and boundless oppressions, has taken over the AKP and, through it, political Islam. In this context, they call the reincarnation of this neo-Ittihatçılık and neoIslamism, the 'New Turkey'.

Çandar's definition proves rather fit for the socio-political alliance that started in 2013 and is still going through its formative process. Yet, it does not look at the internal workings of the system and does not offer insight as to how unofficial Islamic groups, the state, the AKP and Erdoğan interact. The formation of a repressive/authoritarian regime and its synthesis with Islam are closely related to the evolving 'logic' explained above. Islam, in the formation of this 'New Turkey' under the control of Erdoğan's AKP, is being put under stricter control, while being utilised for political purposes. The control over religion is not being executed with a 
restrictive laik mind-set, as throughout Republican history, but with a mind-set that puts Islam in the forefront - yet without relinquishing control. This control over Islam and authoritarianism work jointly to create a new logic that builds the relationship between religion, religious groups and authoritarian government on fear and a concern for survival: a different take from that offered by Koesel, and Kuru. Briefly, despite historical similarities, the relationship between religious groups and authoritarian political structures in Turkey is different from that in Russia, China, Hungary and the MENA region, with all its intricacies that are essentially local. In this regard, one might argue that compared to the laik practices of Kemalism, the AKP does not seem to have changed the fundamental attitude of the state towards religion. The Kemalists controlled religious manifestation in the public space through restrictive measures: the AKP is regulating the public space by infusing religious elements. The state control over religion remains unchanged. Again, reminiscent of the early years of the Republic, a political structure with claims of control over official and unofficial Islam dominates religious discourse and policies through fear - only from the opposite direction. 


\section{References}

Akgönül, S. 2005. Religions de Turquie, religions des Turcs. Nouveaux acteurs dans l'Europe élargie.

Angell, S. W., and Dandelion, P. (Eds.). 2015. Early Quakers and Their Theological Thought: 1647-1723. Cambridge: Cambridge University Press.

Aslan, Ö. 2016. 'Unarmed'We Intervene, Unnoticed We Remain: The Deviant Case of 'February 28th Coup'in Turkey. British Journal of Middle eastern studies, 43, no.3: 360-377.

Atay, T. 2017. Parti, Cemaat, Tarikat [Party, Community, Sect]. İstanbul: Can Sanat Yayınları.

Başer, B., and Öztürk, A. E. 2017. Authoritarian politics in Turkey: elections, resistance and the AKP. London: IB Tauris.

Ben-Porat, G. 2013. Between state and synagogue: The secularization of contemporary Israel, vol. 42. New York: Cambridge University Press.

Berger, P. 1969. Sacred Canopy. New York: Anchor Books.

Bruce, B. 2015. Governing islam abroad: the Turkish and Moroccan Muslim fields in France and Germany, Doctoral dissertation, Paris: Institut d'études politiques.

Casanova, J. 2001a. Civil society and religion: retrospective reflections on Catholicism and prospective reflections on Islam. Social Research, 68, no. 4: 1041-1080.

Casanova, J. 2001b. Religion, the new millennium, and globalization. Sociology of Religion 62, no. 4: 415-441.

Casanova, J. 2012. Public religions in the modern world. Chicago: University of Chicago Press.

Case, W. 1993. Semi-democracy in Malaysia: withstanding the pressures for regime change. Pacific Affairs, 66, no.2: 183-205.

Cesari, J. 2004. When Islam and democracy meet: Muslims in Europe and in the United States. New York: Springer.

Coşgel, M., and Miceli, T. J. 2009. State and religion. Journal of Comparative Economics, 37 , no. 3: 402-416.

Cox, H. 2013. TheSecular city: Secularization and urbanization in theological perspective. Oxfordshire: Princeton University Press. 
Çitak, Z. 2010. Between 'Turkish Islam'and 'French Islam': The role of the diyanet in the conseil Français du culte musulman. Journal of Ethnic and Migration Studies, 36, no.3: 619634.

Driessen, M. D. 2014. Religion and democratization: framing religious and political identities in Muslim and Catholic societies. Oxford: Oxford University Press.

Elshtain, J. B. 2009. Religion and democracy. Journal of Democracy, 20, no.2:5-17.

Encarnación, O. 2003. The myth of civil society: social capital and democratic consolidation in Spain and Brazil. New York: Springer.

Farr, T. F. 2008. Diplomacy in an Age of Faith-Religious Freedom and National Security. Foreign Affairs, 87, no.2: 110-124.

Fox, J. 2008. A world survey of religion and the state. Cambridge: Cambridge University Press.

Fox, J., and Flores, D. 2009. Religions, constitutions, and the state: A cross-national study. The Journal of Politics, 71, no. 4: 1499-1513.

Fox, J., and Sandal, N. 2013. Religion in international relations theory: interactions and possibilities. London: Routledge.

Froese, P., and Mencken, F. C. 2009. A US holy war? The effects of religion on Iraq war policy attitudes. Social Science Quarterly, 90, no. 1: 103-116.

Gill, A. 2002. The study of liberation theology: What next?. Journal for the Scientific Study of Religion, 41, no. 1: 87-89.

Gözaydın, I. B. 2008. Diyanet and politics. The Muslim World, 98, no. 2-3: 216-227.

Gözaydın, İ. 2009. Diyanet. [the Diyanet]. İstanbul: İletişim Yayınları.

Gunter, M. M., and Hakan Yavuz, M. 2007. Turkish paradox: Progressive Islamists versus reactionary secularists. Critique: Critical Middle Eastern Studies, 16, no. 3: 289-301.

Gurses, M., and Rost, N. 2017. Religion as a peacemaker? Peace duration after ethnic civil wars. Politics and Religion, 10, no.2: 339-362.

Habermas, J. 2008. Notes on post-secular society. New perspectives quarterly, 25, no. 4: 1729.

Hale, W., and Ozbudun, E. 2009. Islamism, democracy and liberalism in Turkey: The case of the AKP. London: Routledge.

Hanson, E. O. 2006. Religion and Politics in the International System Today. Cambridge: Cambridge University Press.

Harris, G. S. 1979. Islam and the state in modern Turkey. Middle East Review, 11, no.4: 21-46. 
Haynes, J. 1994. Religion in Third World politics. Boulder, CO: Lynne Rienner.

Haynes, J. 2006. Islam and democracy in East Africa. Democratization, 13, no. 3: 490-507. Hirschman, C. 2004. The Role of Religion in the Origins and Adaptation of Immigrant Groups in the United States 1. International Migration Review, 38, no.3: 1206-1233.

Hurd, E. S. 2004. The political authority of secularism in international relations. European Journal of International Relations, 10, no.2: 235-262.

Inglehart, R., and Norris, P. 2004. Sacred and secular. Religion and politics worldwide. Cambridge: Cambridge University Press.

Insel, A. 2003. The AKP and normalizing democracy in Turkey. The South Atlantic Quarterly,102, no.2: 293-308.

Juergensmeyer, M. 1993. The new cold war? Religious nationalism confronts the secular state. California: University of California Press.

Kalyvas, S. N. 2000. Commitment problems in emerging democracies: The case of religious parties. Comparative Politics, 32, no. 4: 379-398.

Katzenstein, P. J., and Byrnes, T. A. 2006. Transnational religion in an expanding Europe. Perspectives on Politics, 4, no.4: 679-694.

Koesel, K. J. 2013. The rise of a Chinese house church: The organizational weapon. The China Quarterly, 215: 572-589.

Koesel, K. J. 2014. Religion and authoritarianism: Cooperation, conflict, and the consequences. Cambridge: Cambridge University Press.

Kubálková, V. 2000. Towards an international political theology. Millennium, 29, no.3: 675704.

Kuru, A. T. 2014. Authoritarianism and democracy in Muslim countries: rentier states and regional diffusion. Political Science Quarterly, 129, no. 3: 399-427.

Levitsky, S., and Way, L. A. 2010. Competitive authoritarianism: Hybrid regimes after the Cold War. Cambridge: Cambridge University Press.

Lord, C. 2018. Religious Politics in Turkey: From the Birth of the Republic to the AKP. Cambridge: Cambridge University Press.

Mardin, S. 1989. Religion and social change in modern Turkey: The case of Bediuzzaman Said Nursi. New York: Suny Press.

Mardin, Ş. A. 1971. Ideology and religion in the Turkish revolution. International Journal of Middle East Studies, 2, no.3: 197-211.

McCleary, R. M., and Barro, R. J. 2006. Religion and economy. Journal of Economic perspectives, 20 , no.2, 49-72. 
Mutluer, N. 2014. A Case for Pluralism: The Alevis' Latest Struggle Against Discrimination. Turkish Policy Quarterly, 13, no. 1: 149-158.

Norris, P. 2017. Strengthening electoral integrity. Cambridge: Cambridge University Press.

Norris, P.,and Inglehart, R. 2011. Sacred and secular: Religion and politics worldwide. Cambridge: Cambridge University Press.

Ozzano, L., and Maritato, C. 2018. Patterns of Political Secularism in Italy and Turkey: The Vatican and the Diyanet to the Test of Politics. Politics and Religion, 1-21. https://doi.org/10.1017/S1755048318000718.

Öztürk, A. E. 2014. The presidential election in Turkey: History and future expectations. Contemporary Southeastern Europe, 1, no. 2: 110-118.

Öztürk, A. E. 2016. Turkey's Diyanet under AKP rule: from protector to imposer of state ideology?. Southeast European and Black Sea Studies, 14, 4: 619-635.

Öztürk, A. E. 2018. Lack of self-confidence of the authoritarian regimes and academic freedom: the case of İştar Gözaydın from Turkey. European Political Science, 1-10. https://doi.org/10.1057/s41304-018-0170-y.

Öztürk, A. E., and Gözaydın, İ. 2018. A Frame for Turkey's Foreign Policy via the Diyanet in the Balkans. Journal of Muslims in Europe, 7, no.3: 331-350.

Öztürk, A. E., and Sözeri, S. 2018. Diyanet as a Turkish foreign policy tool: Evidence from the Netherlands and Bulgaria. Politics and Religion, 11, no.3: 624-648.

Sakallioğlu, Ü. C. 1996. Parameters and strategies of Islam-State interaction in Republican Turkey. International Journal of Middle East Studies, 28, no. 2: 231-251.

Sandal, N. A., and James, P. 2011. Religion and international relations theory: Towards a mutual understanding. European Journal of International Relations, 17, no. 1: 3-25.

Sarkissian, A., Fox, J., and Akbaba, Y. 2011. Culture vs. rational choice: Assessing the causes of religious discrimination in Muslim states. Nationalism and Ethnic Politics, 17, no.4: 423446.

Schedler, A. 2013. The politics of uncertainty: Sustaining and subverting electoral authoritarianism. Oxford: Oxford University Press.

Simpson, D. J. 1965. Development as a process: the Menderes phase in Turkey. The Middle East Journal, 19, no.2: 141-152.

Smith, A. D. 1999. Ethnic election and national destiny: some religious origins of nationalist ideals. Nations and Nationalism, 5, no. 3: 331-355.

Snyder, J. 2011. Religion and international relations theory. Columbia: Columbia University Press. 
Stepan, A. C. 2000. Religion, democracy, and the" twin tolerations". Journal of democacy, 11, no.4: 37-57.

Taş, H. 2015. Turkey-from tutelary to delegative democracy. Third World Quarterly, 36, no. 4: 776-791.

Taş, H. 2018. A history of Turkey's AKP-Gülen conflict. Mediterranean Politics, 23, no.3: 395-402.

Warner, R. S. 2000. Religion and new (post-1965) immigrants: Some principles drawn from field research. American Studies, 41, no. 2/3: 267-286.

Watmough, S. P., \& Öztürk, A. E. 2018a. From 'Diaspora by Design'to Transnational Political Exile: The Gülen Movement in Transition. Politics, Religion \& Ideology, 19, no.1: 33-52.

Watmough, S. P., \& Öztürk, A. E. 2018b. The Future of the Gülen Movement in Transnational Political Exile: Introduction to the Special Issue. Politics, Religion \& Ideology, 19, no.1: 1-10.

Yavuz, M. H. 1997. Political Islam and the welfare (Refah) party in Turkey. Comparative Politics, 30, no. 1: 63-82.

Yavuz, M. H. 1999. Towards an Islamic liberalism?: the Nurcu movement and Fethullah Gülen. The Middle East Journal, 53, no. 4: 584-605.

Yeşilada, B. A. 2002. The Virtue Party. Turkish Studies, 3, no. 1: 62-81.

Zakaria, F. 1997. The rise of illiberal democracy. Foreign Affairs, 76, no. 6: 22-43.

i For the details of the Freedom House 2017 Report, namely; 'Populists and Autocrats: The Dual Threat to Global Democracy', see; https://freedomhouse.org/report/freedom-world/freedom-world2017.

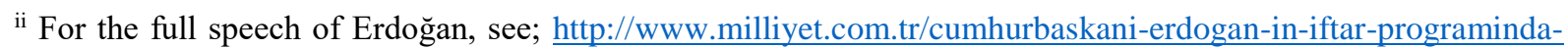
diyarbakir-yerelhaber-2845760/.

iii The details of the issue see; https://www.bbc.com/news/10203726.

iv For details see, Adam Lusher's explanatory op-ed; https://www.independent.co.uk/news/world/turkey-coupconspiracy-theory-erdogan-military-gift-from-god-soldiers-istanbul-a7140516.html.

$\mathrm{v}$ There is a very detailed explanation on which unofficial Islamic group support Erdoğan openly; https://fotogaleri.haberler.com/hangi-cemaat-hangi-partiye-oy-verecek-menzil/.

${ }^{v i} 21$ members of religious Furkan Foundation, including head, detained after their open critics to Erdoğan, see; http://www.hurriyetdailynews.com/21-members-of-religious-furkan-foundation-including-head-detained-inturkeys-adana-126510. 